\title{
ELECTROCHEMICAL DETERMINATION OF DOPAMINE AND URIC ACID USING POLY(PROLINE) MODIFIED CARBON PASTE ELECTRODE: A CYCLIC VOLTAMMETRIC STUDY
}

\author{
Edwin S. D' Souza' ${ }^{1}$,Jamballi G. Manjunatha ${ }^{1,}{ }^{凶}$, Chenthattil Raril $^{1}$
}

https://doi.org/10.23939/chcht15.02.153

\begin{abstract}
A cyclic voltammetric technique was used for electropolymerisation of proline on the surface of carbon paste electrode and for individual and concurrent determination of dopamine (DA) and uric acid (UA). The surface morphology of the developed electrode was studied by using field emission scanning electron microscopy. The modified electrode showed a high current response towards DA as compared to the bare electrode. The modified electrode shows good catalytic activity with a different oxidation potential of dopamine and UA. The electrode process was found to be adsorption controlled. The developed method shows very good stability and reproducibility. Under the optimized conditions, the concentration range is $(1-2) \cdot 10^{-4} \mathrm{M}$ and the observed detection limit was $4.7 \cdot 10^{-6} \mathrm{M}$. The developed sensor was applied for the determination of DA in the real sample with a good recovery.
\end{abstract}

Keywords: dopamine, uric acid, proline, electropolymerization, cyclic voltammetry.

\section{Introduction}

Dopamine (DA) and uric acid (UA) are two important neurotransmitters distributed in mammals. DA is an essential molecule of catecholamine present in the mammalian central nervous system for the transfer of signals. Its deficiency leads to brain disorders such as Parkinson's disease and schizophrenia [1-3]. UA is the primary final product of purine metabolism found in urine and blood. Its significant concentration in human body is the indication of a number of diseases such as hypothyroidism, gout, lactic acidosis, and hyperuricemia [4-8]. It is essential to develop sensitive and selective methods for the detection of DA and UA. Different electrodes have been used to study these biological

\footnotetext{
${ }^{1}$ Department of Chemistry, FMKMC College, Madikeri, Constituent College of Mangalore University, Karnataka, India

\manju1853@gmail.com

(c) D’Souza E., Manjunatha J., Raril C., 2021
}

molecules from a long time. A lot of advantages were found in polymer modified electrodes (PMEs) because of their sensitivity, selectivity, and homogeneity in electrochemical deposition, strong adherence to the electrode surface and stability [9-10]. To study the electrochemical oxidation of DA and UA, various PMEs are used. Cyclic voltammetric $(\mathrm{CV})$ technique provides a simple and fast way of analyzing biological and environmentally important molecules [11-17]. For instance, a glassy carbon electrode (GCE) modified with $\operatorname{poly}(N, N$-dimethylaniline) could simultaneously identify ascorbic acid and DA, which coexist in true solution [18]. It is also found that glutamic acid [19], aminobenzoic acid [20], and $p$-nitrobenzo resorcinol [21] as an electropolymerized layer are used to modify GCE for the identification of DA. The conducting polymer with nanoparticles of metallic or semiconducting materials finds a number of applications in electronics, sensors, and catalysis [22-24]. They have synergistic physical and chemical properties based on the constituent polymer and introduced metal. Thus, setting a polymer with nanoscale material, it is possible to develop nano-electronic sensors with the superior performance [25-27].

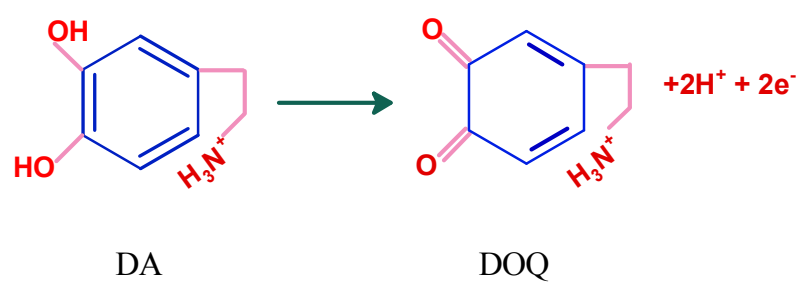

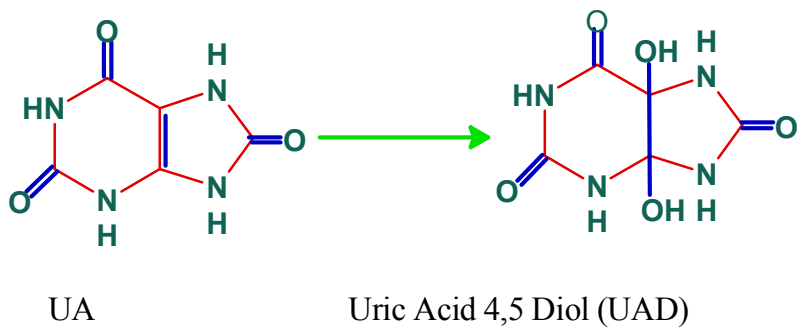

Fig. 1. The oxidation mechanism of DA and UA 
This work involves the development of poly(proline) on the surface of a carbon paste electrode (CPE) by $\mathrm{CV}$ technique. The polymer was found electrocatalytically active for the electro-oxidation of DA. The oxidation potential of DA could distinguish from UA with its good sensitivity, selectivity, and stability. Recently a lot of work has been performed on the topic [28-37]. The scheme for the oxidations of DA and UA is shown in Fig. 1 [29].

\section{Experimental}

\subsection{Apparatus and Reagents}

The CV experiments were performed with a model of EA-201 Electro analyzer (Chemilink systems, India) connected to a personal computer for the control and data storage. A standard three-electrode cell is used to carry out all electrochemical experiments. The bare (BCPE) or poly(proline) modified CPE (PPMCPE) was used as a working electrode, platinum wire - as a counter electrode and saturated calomel electrode (SCE) - as a reference electrode.

DA, UA, and proline were obtained from Himedia chemicals, Bangalore, India and used. The other solutions were of analytical grades: phosphate buffer solutions (PBS, 0.2M) prepared by mixing standard solutions of $0.2 \mathrm{M}$ disodium hydrogen phosphate and sodium dihydrogen phosphate. For all the experiments, freshly prepared solutions of DA $\left(25 \cdot 10^{-4} \mathrm{M}\right)$ and UA $\left(25 \cdot 10^{-4} \mathrm{M}\right)$ are used. The stock solution of proline $\left(25 \cdot 10^{-3} \mathrm{M}\right)$ and other solutions were prepared in distilled water.

\subsection{Preparation of $B C P E$}

CPE was prepared by hand mixing of silicone oil and graphite powder in the ratio of $30: 70(\mathrm{w} / \mathrm{w})$ in an agate mortar until a homogeneous paste is produced. The prepared carbon paste was packed tightly into a Teflon tube ( $3 \mathrm{~mm}$ internal diameter) and the electrical contact was provided by a copper wire connected to the paste at the end of the tube.

\subsection{Preparation of PPMCPE}

$1 \mathrm{mM}$ proline solution was placed in an electrochemical cell containing $0.2 \mathrm{M}$ PBS ( $\mathrm{pH}$ 7.4). The poly(proline) modified CPE was prepared by scanning the proline solution in the potential range from -1300 to $1800 \mathrm{mV}$ at the scan rate of $100 \mathrm{mV} / \mathrm{s}$ for five times. The prepared electrode is rinsed with water to remove unreacted proline monomer and used for the determination of DA and UA. The cyclic voltammograms are shown in Fig. 2.

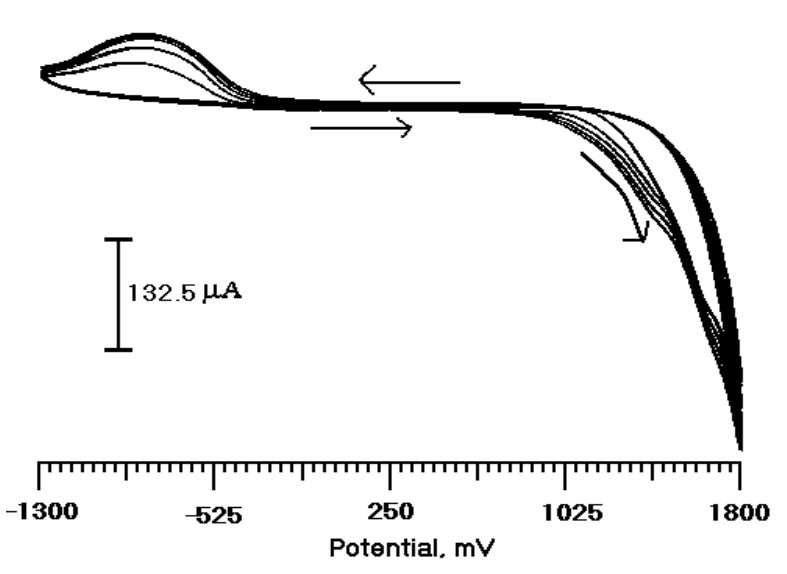

Fig. 2. $\mathrm{CVs}$ for the electropolymerization of $1 \mathrm{mM}$ proline at BCPE in 0.2M PBS ( $\mathrm{pH} 7.4)$ at the scan rate of $100 \mathrm{mV} / \mathrm{s}$

\section{Results and Discussion}

\subsection{Characterization}

Fig. 3 shows the characteristic surface morphologies BCPE and PPMCPE by using Field Emission Scanning Electron Microscopy (FE-SEM). It is seen that the surface of BCPE (Fig. 3a) have irregular shaped carbon flakes. But, PPMCPE has a symmetrical arrangement of poly(proline) layer on the surface of BCPE (Fig. 3b). It shows that the surface of BCPE is covered by poly(proline) film.

\subsection{Electrochemical Investigation of Potassium Ferrocyanide at PPMCPE}

To study the electrochemical behavior of PPMCPE, potassium ferrocyanide $\mathrm{K}_{4}\left[\mathrm{Fe}(\mathrm{CN})_{6}\right]$ was used as electrochemical redox probe (Fig. 4a). The cyclic voltammograms of $\mathrm{K}_{4}\left[\mathrm{Fe}(\mathrm{CN})_{6}\right]$ show that the redox peak current increases compared to bare CPE. The cyclic voltammogram of $\mathrm{K}_{4}\left[\mathrm{Fe}(\mathrm{CN})_{6}\right]$ (solid line) at the bare is $230 \mathrm{mV}$, and the peak potential at the cathode is $159 \mathrm{mV}$ in $1 \mathrm{M} \mathrm{KCl}$. PPMCPE shows a pair of redox peaks (dashed line). The anodic peak potential was found to be at $230 \mathrm{mV}$ and the cathodic peak potential - at $175 \mathrm{mV}$. It showed an excellent catalytic activity of PPMCPE . The cyclic voltammogram of $\mathrm{K}_{4}\left[\mathrm{Fe}(\mathrm{CN})_{6}\right]$ at different scan rates from 100 to $250 \mathrm{mV} / \mathrm{s}$ is shown in Fig. $4 \mathrm{~b}$. It is observed that the peak current of PPMCPE increased 
much higher than that of BCPE. Due to the increase in peak current at the modified electrode, it indicates that

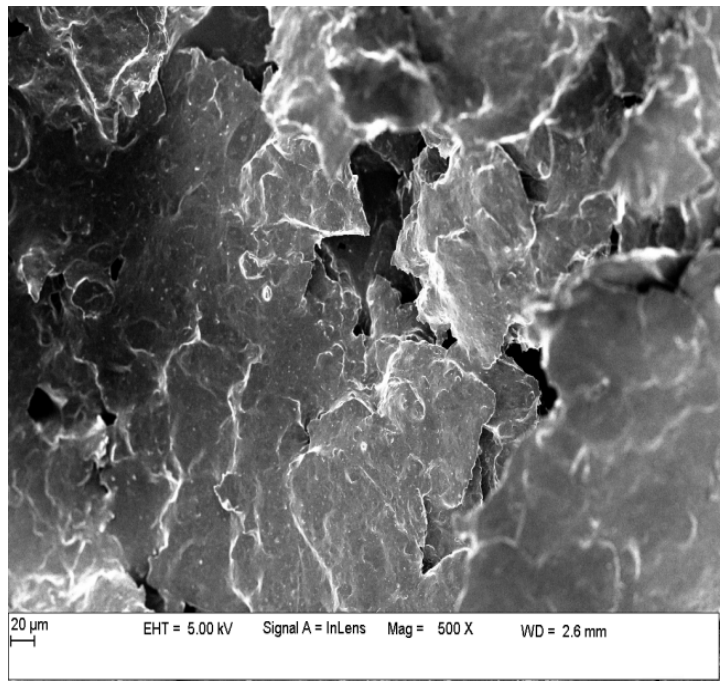

a) the modified electrode possesses the highest electrocatalytic activity.

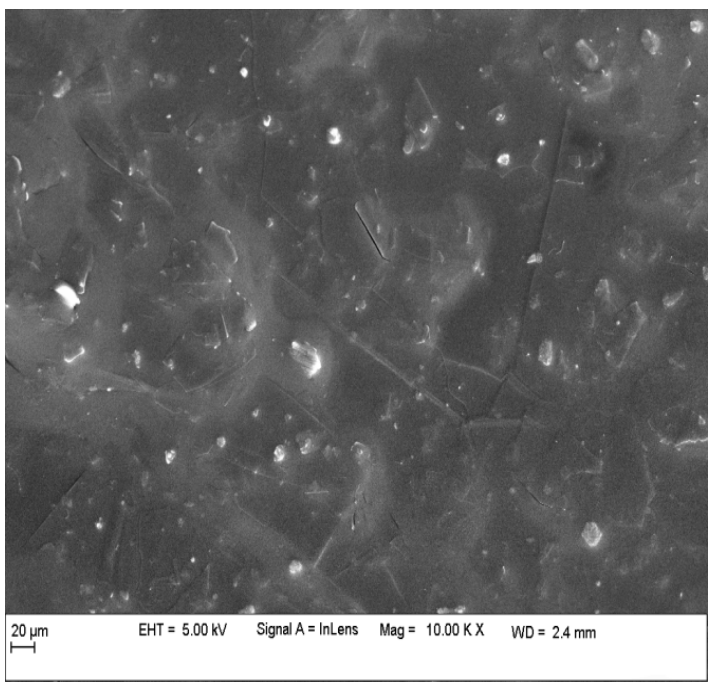

b)

Fig. 3. FE-SEM image of BCPE(a) and PPMCPE (b)

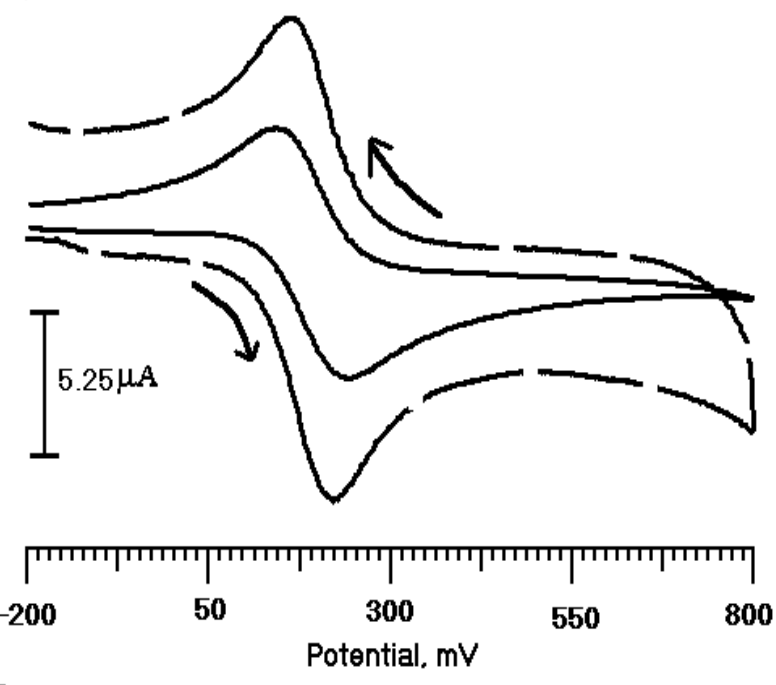

a)

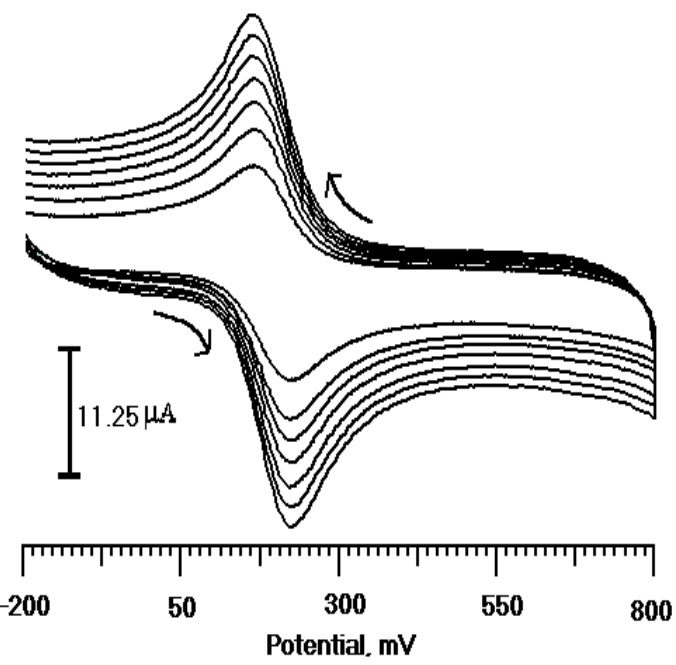

b)

Fig. 4. $\mathrm{CVs}$ for the electrochemical responses of $\mathrm{K}_{4}\left[\mathrm{Fe}(\mathrm{CN})_{6}\right]$ at bare (solid line) and PPMCPE (dashed line) in $1 \mathrm{M} \mathrm{KCl}$ containing $1 \mathrm{mM}$ of at the scan rate of $100 \mathrm{mV} / \mathrm{s}(\mathrm{a})$; $\mathrm{CVs}$ of $\mathrm{K}_{4}\left[\mathrm{Fe}(\mathrm{CN})_{6}\right]$ at PPMCPE with different scan rates $(100-250 \mathrm{mV} / \mathrm{s})(\mathrm{b})$

\subsection{Electrochemical Response of DA at PPMCPE}

Fig. 5 shows the voltamogramms of blank solution (PBS, $\mathrm{pH}$ 6.5), and no peak is observed for blank (solid line). However, when DA $\left(1 \cdot 10^{-4}\right) \mathrm{M}$ is added to the solution (dashed line), a standard peak is observed at the potential of $168 \mathrm{mV}\left(E_{p a}\right)$ with the peak current $\left(I_{p a}\right)$ of
$16.32 \mu \mathrm{A}$ and $137 \mathrm{mV}\left(E_{p c}\right)$ with the peak current $\left(I_{p c}\right)$ of $10.12 \mu \mathrm{A}$. Such significant increase in the peak current gives evidence of electrocatalytic effect.

The CVs of DA is shown in Fig. 6 at BCPE (solid line) and PPMCPE (dashed line). The peak current at the modified electrode is much higher than that of the bare. This shows that the electrochemical oxidation of DA is improved at PPMCPE. 


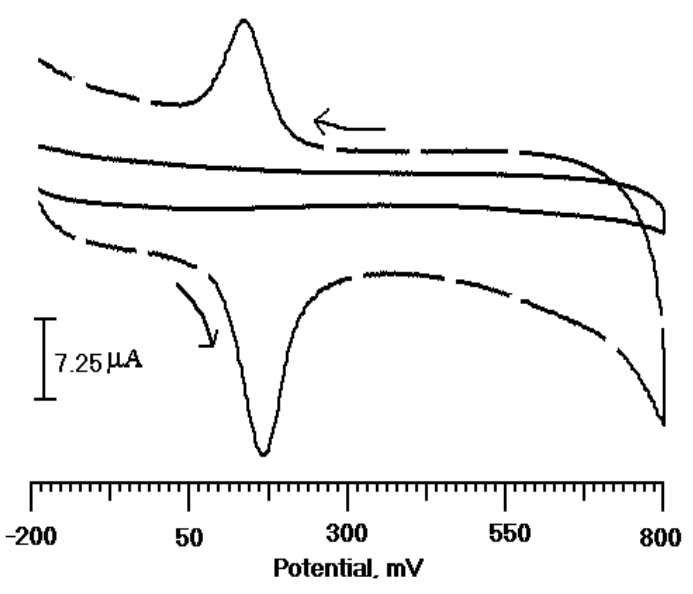

Fig. 5. Cyclic voltammograms of DA $\left(1 \cdot 10^{-4} \mathrm{M}, 0.2 \mathrm{M}\right.$ PBS, $\mathrm{pH}$ 6.5) at PPMCPE (dashed line) and blank solution (solid line)

\subsection{Effect of Scan Rate on the Peak Currents of DA}

Scan rate can affect the current responses of DA, and corresponding parameters could be obtained from the relationship between the scan rate and the current reactions of DA. The effect of scan rate of electrooxidation of DA at PPMCPE in 0.2M PBS (pH 6.5) is shown in Fig. 7a. It is observed that as the scan rate increases, the oxidation peak current increases too. The peak current of DA shows a linear relationship with scan rate in the range of $100-250 \mathrm{mV} / \mathrm{s}$ with regression equation $I_{p a}(\mu \mathrm{A})=3.79+0.213 v$ and the correlation coefficient of 0.998 (Fig. 7b), which confirms that the electrode process is adsorption controlled.

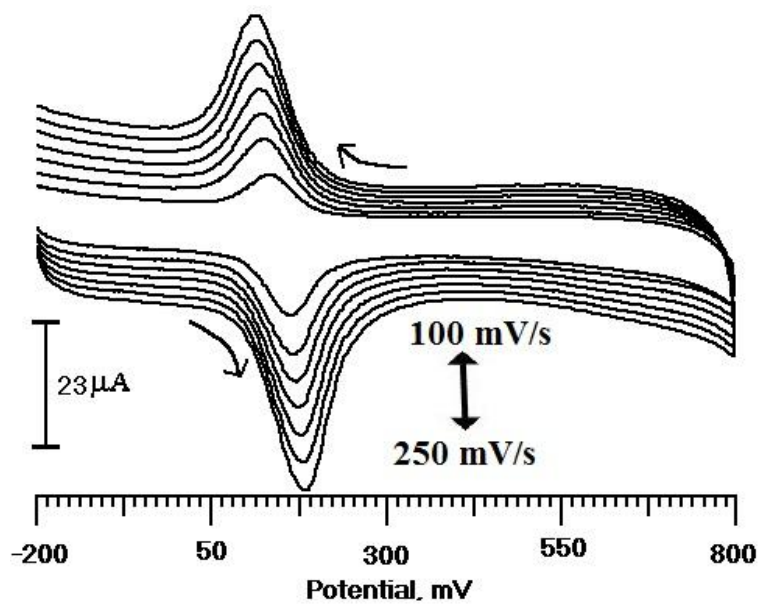

a)

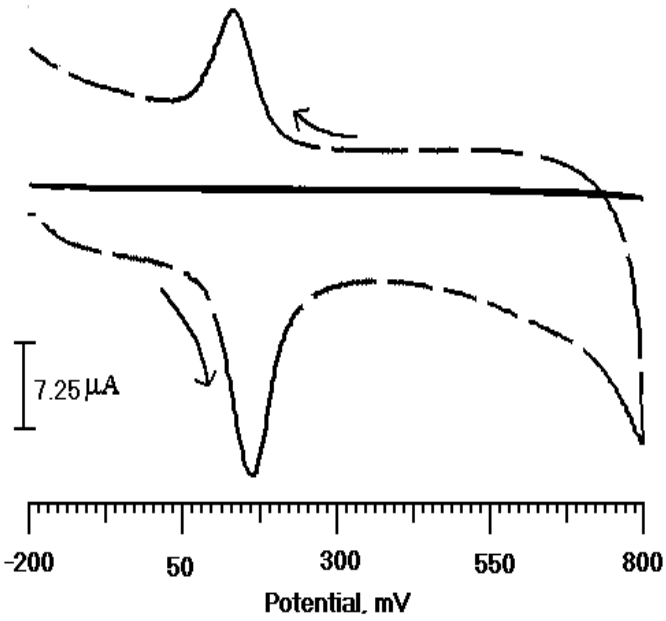

Fig.6. Cyclic voltammogram of DA $\left(1 \cdot 10^{-4} \mathrm{M}, 0.2 \mathrm{M}\right.$ PBS, $\mathrm{pH}$ 6.5) at BCPE (solid line) and PPMCPE (dashed line)

\subsection{Effect of pH Value on DA Behavior}

Effect of $\mathrm{pH}$ on DA at PPMCPE in the $\mathrm{pH}$ range of $6-8$ is depicted in Fig. 8a. The maximum peak current is seen at $\mathrm{pH} 6.5$ (Fig. 8b). For the better sensitivity and selectivity $\mathrm{pH}$ of 6.5 is taken as optimum for the determination of DA. The peak potential was shifted to lower positive side with higher buffer $\mathrm{pH}$, showing that the proton takes part in the electrode reaction and obey the equation $E_{p a}(\mathrm{mV})=625-67.8 \mathrm{pH}$ with the correlation coefficient of 0.978 (Fig. 8c). The slope of the equation was found to be $-67.8 \mathrm{mV} / \mathrm{pH}$. The obtained graph is very close to the expected theoretical value of $-59 \mathrm{mV} / \mathrm{pH}$, which suggests that the number of electrons transferred is equal to the number of hydrogen ions taking part in the electrode reaction.

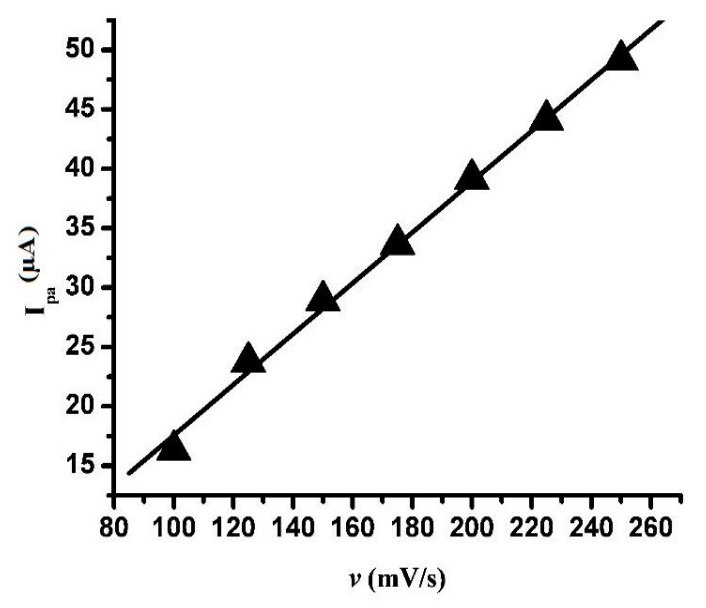

b)

Fig. 7. CVs of DA $\left(1 \cdot 10^{-4} \mathrm{M}, 0.2 \mathrm{M}\right.$ PBS, pH 6.5) at PPMCE at scan rates of $100,125,150,175,200,225$ and $250 \mathrm{mV} / \mathrm{s}$ (a); Anodic peak current vs. scan rate (b) 


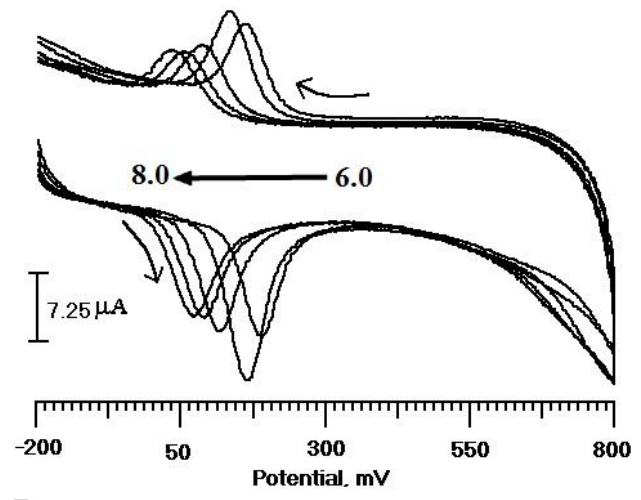

a)

Fig. 8. CVs of DA $\left(1 \cdot 10^{-4} \mathrm{M}\right)$ at PPMCPE

in $0.2 \mathrm{M}$ PBS at $\mathrm{pH}$ values of $6.0,6.5,7.0,7.5$ and $8.0(\mathrm{a})$;

Anodic peak current $v s . \mathrm{pH}(\mathrm{b})$; Potential $v$ s. $\mathrm{pH}$ (c)

\subsection{Calibration Plot and Limit of Detection for DA}

$\mathrm{CV}$ was a sensitive electrochemical method used to determine the linear range and the limit of detection. The CV of DA at PPMCPE in the concentration range from $1 \cdot 10^{-4}$ to $2 \cdot 10^{-4} \mathrm{M}$ in PBS ( $\mathrm{pH} 6.5$ ) is determined. Fig. 9 shows the relation between the peak current and DA concentrations. A linear calibration curve is obtained according to the linear equation $I_{p a}(\mathrm{~A})=3.15 \cdot 10^{-6}+0.01 \mathrm{C}$ (M) and the correlation coefficient is 0.99 . The detection limit (LOD) and limit of quantification (LOQ) were calculated by the simple equation LOD $=3 S / N$ and $\mathrm{LOQ}=10 S / N$, where $S$ is the standard deviation of the blank solution and $N$ is the slope of the calibration curve. The values obtained are $4.7 \cdot 10^{-6} \mathrm{M}$ and $15.7 \cdot 10^{-6} \mathrm{M}$, respectively. The detection limit values compared with

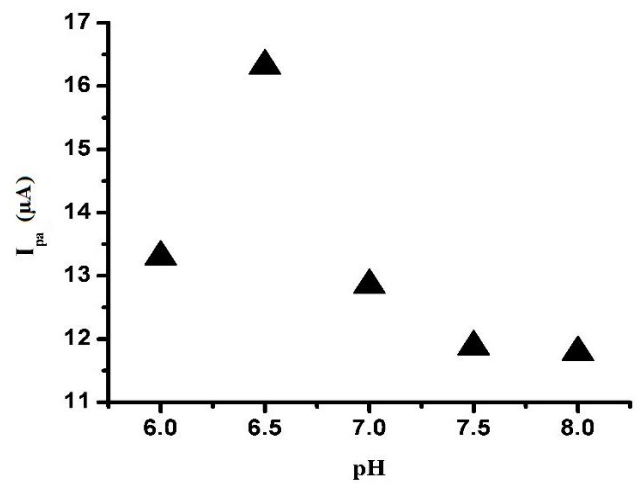

b)

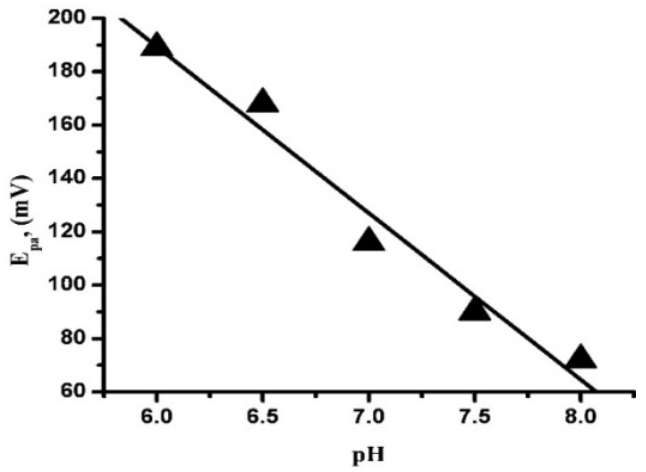

c)

some modified electrodes are represented in the Table [38-40].

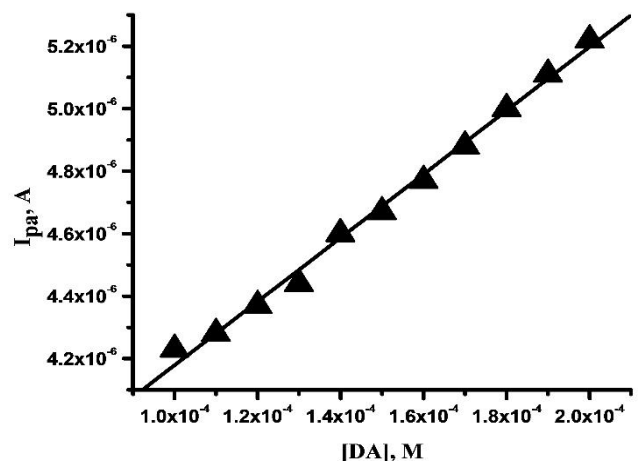

Fig. 9. Calibration plot for the determination of DA at PPMCPE in 0.2M PBS (pH 6.5) at the scan rate of $100 \mathrm{mV} / \mathrm{s}$

Table

Comparison of PPMCPE with some modified electrodes for the determination of dopamine

\begin{tabular}{|c|c|c|c|c|}
\hline Electrode & Analyte & Linear range, M & Detection limit, M & Ref. \\
\hline $\begin{array}{c}\text { Sodium dodecyl sulphate/carbon nanotube } \\
\text { paste electrode }\end{array}$ & DA & $1 \cdot 10^{-6}$ to $2.8 \cdot 10^{-5}$ & $3.3 \cdot 10^{-7}$ & {$[38]$} \\
\hline $\begin{array}{c}\text { Glassy carbon electrode/poly(caffeic acid) } \\
\text { Indole-3-carboxaldehyde/glassy carbon } \\
\text { electrode }\end{array}$ & DA & $1 \cdot 10^{-6}$ to $4 \cdot 10^{-5}$ & $4 \cdot 10^{-7}$ & {$[39]$} \\
\hline PPMCPE & DA & $10 \cdot 10^{-6}$ to $10 \cdot 10^{-4}$ & $17 \cdot 10^{-7}$ & {$[40]$} \\
\hline \multicolumn{2}{|l}{} & $1 \cdot 10^{-4}$ to $2 \cdot 10^{-4}$ & $4.7 \cdot 10^{-6}$ & This work \\
\hline
\end{tabular}




\subsection{Electrochemical Behavior of UA at PPMCPE}

Fig. 10a represents the electrochemical oxidation of $1 \cdot 10^{-4} \mathrm{M}$ UA at BCPE (solid line) and PPMCPE (dashed line). The anodic peak potential for the oxidation of DA is $291 \mathrm{mV}$ with the peak current of $1.48 \mu \mathrm{A}$ for BCPE while for PPMCPE the peak potential is $302 \mathrm{mV}$ with the peak current of $14.06 \mu \mathrm{A}$. Thus, it is evident that the PPMCPE gives increased peak current and shows strong electrocatalytic effect.

The experiment was conducted at different scan rates to study the electrode reaction, and the CVs of $1 \cdot 10^{-4} \mathrm{M}$ UA at PPMCPE is shown in Fig. 10b. Peak current increases with the increase in the scan rate. This indicates the electron transfer between UA and the modified electron surface. The scan rate in the range of $100-250 \mathrm{mV} / \mathrm{s}$ with a linear regression of $I_{p a}=-9.25+0.05 v$ (Fig. 10c) and correlation coefficient of 0.976 shows that it is adsorption controlled electrode reaction.
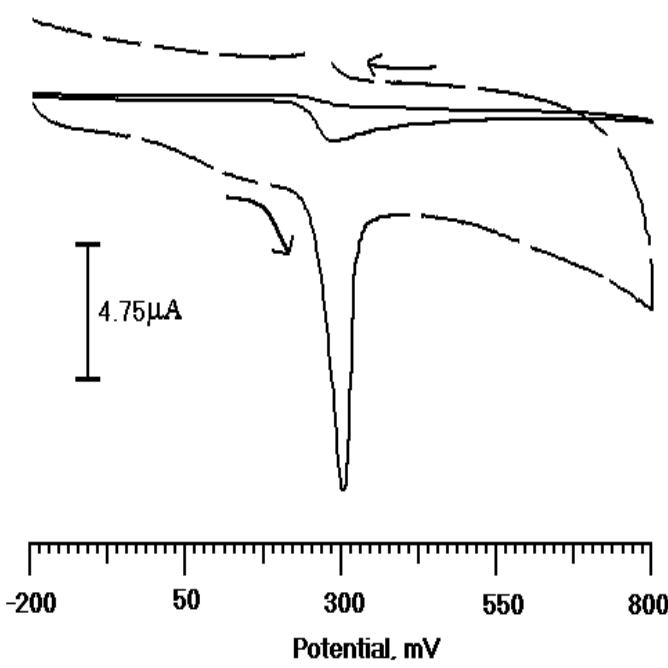

a)

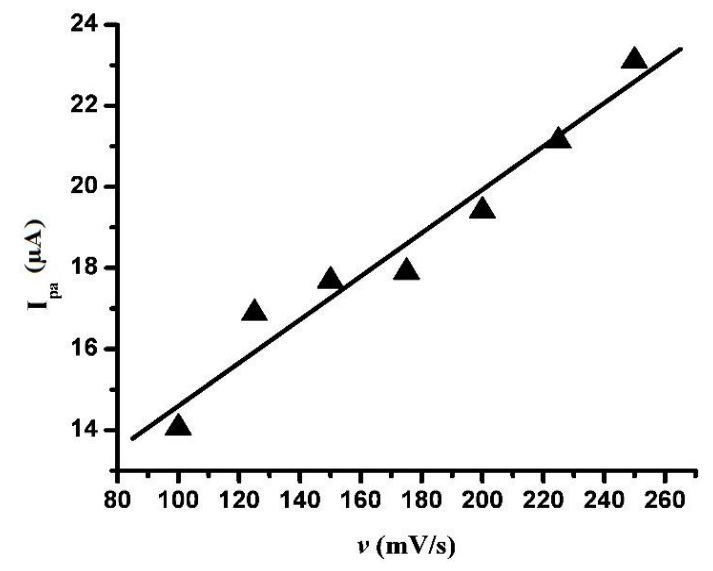

c)

\subsection{Simultaneous Determination of DA and UA at PPMCPE by CV and Differential Pulse Voltammetry (DPV)}

DA and UA exist together in the extracellular fluid of the central nervous system. The oxidative potentials of both are very close to one another. Simultaneous determination is the primary purpose of the study. Fig. 11a represents the CVs of DA $\left(1 \cdot 10^{-4} \mathrm{M}\right)$ and $\mathrm{UA}\left(1 \cdot 10^{-4} \mathrm{M}\right)$ in $0.2 \mathrm{M}$ PBS ( $\mathrm{pH} 6.5$ ) at the scan rate of $100 \mathrm{mV} / \mathrm{s}$. A well defined two oxidation peaks are obtained at 148 and $281 \mathrm{mV}$ for DA and UA, respectively. Thus, PPMCPE was effectively used for the separation of DA in the presence of UA. The results of DPV studies of DA and UA in the mixture are shown in Fig. $11 \mathrm{~b}$ and a wellseparated peak for DA and UA at PPMCPE is observed. Therefore, PPMCPE was effectively used to separate DA in the presence of UA.

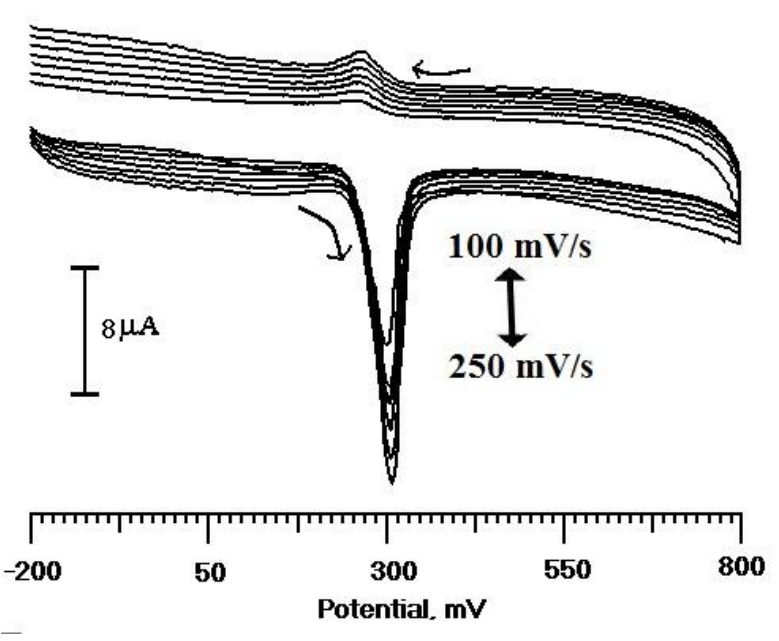

b)

Fig. 10. CVs of UA $\left(1 \cdot 10^{-4} \mathrm{M}\right)$ at BCPE (solid line) and PPMCPE (dashed line) in 0.2M PBS, pH 6.5 (a); CVs of UA $\left(1 \cdot 10^{-4} \mathrm{M}\right)$ at PPMCPE in 0.2M PBS, pH 6.5 at the scan rates of 100, 125, 150, 175, 200, 225 and $250 \mathrm{mV} / \mathrm{s} \mathrm{(b);} \mathrm{Anodic} \mathrm{peak}$ current $v s$. scan rate (c) 


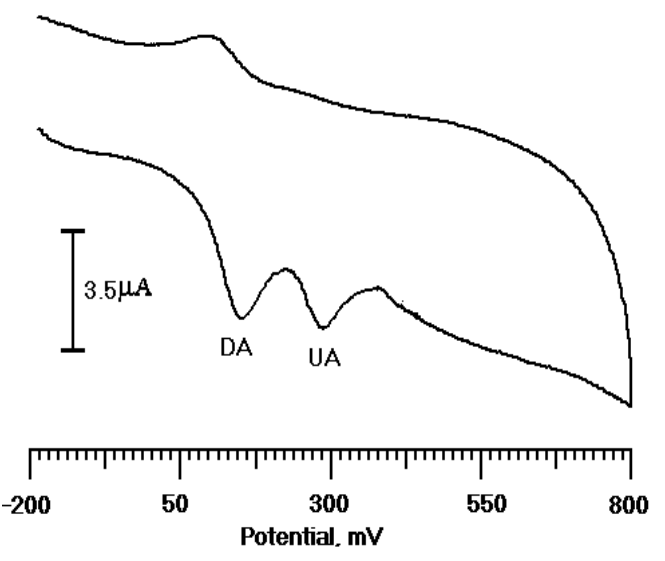

a)
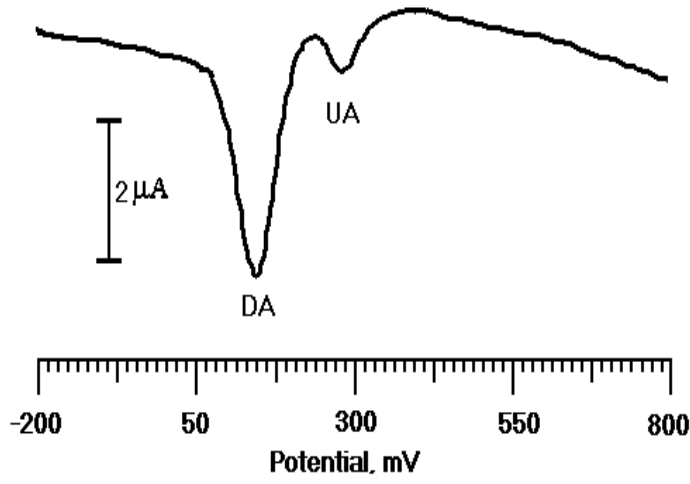

b)

Fig. 11. CVs (a) and DPV (b) obtained at the PPMCPE of a solution containing DA $\left(1 \cdot 10^{-4} \mathrm{M}\right)$ and UA $\left(1 \cdot 10^{-4} \mathrm{M}\right)$ in $0.2 \mathrm{M}$ PBS (pH 6.5)

\subsection{Stability, Reproducibility and Real Sample Analysis}

Stability and reproducibility of the modified electrode are carried out to determine the performance of the sensors. The modified electrode stability is checked by detecting $1 \cdot 10^{-4} \mathrm{M}$ DA on 40 consecutive cycles. A good electrocatalytic response is shown by the sensor, and it confirms that the modified electrode has an excellent stability of $95.69 \%$ current retention. The relative deviation was found to be $3.32 \%$ (4 runs) showing that the modified electrode has good reproducibility.

To revise the application of DA in a real sample, DA injection was purchased from the nearest medical store. The experimentation was carried out by the typical standard addition technique. It was found that the recovery was in the range of 98.40-102.75\%. The results showed that the developed electrochemical sensor is very useful for the resolution of DA in the pharmaceutical sample.

\section{Conclusions}

A sensor was developed using PPMCPE for the determination of DA in the presence of UA. The method used is direct, sensitive, and cost-effective. Sophisticated instruments are not required. The electropolymerization of proline on carbon paste electrode produces a stable polymeric film. PPMCPE exhibits unusual activity towards the DA oxidation, and two well defined voltammetric peaks of DA and UA are obtained. Thus, it is expected that PPMCPE could hold a number of applications in the field of electroanalytical chemistry and biosensors.

\section{Acknowledgements}

We are grateful to acknowledge the financial support from the VGST, Bangalore under the Research Project No. KSTePS/VGST-KFIST (L1) 20162017/GRD-559/2017-2018/126/333, 21/11/207.

\section{References}

[1] Marceglia S., Foffani G., Bianchi A. et al.: J. Physiol., 2006, 571, 579. https://doi.org/10.1113/jphysiol.2005.100271

[2] Wightman R., May L., Michael A.: Anal. Chem. 1998, 60,

769A. https://doi.org/10.1021/ac00164a001

[3] Heinz A., Przuntek H., Winterer G., Pietzcker A.: Nervenarzt, 1995, 66, 662.

[4] Rice C., Birnbaum L., Cogliano J. et al.: Environ. Health Perspect., 2003, 111, 1683. https://doi.org/10.1289/ehp.5798

[5] Colborn T., Vom Saal F., Soto A.: Environ. Health Perspect., 1993, 101, 378. https://doi.org/10.1289/ehp.93101378

[6] Jobling S., Nolan M., Tyler C. et al.: Environ. Sci. Technol., 1998, 32, 2498. https://doi.org/10.1021/es9710870

[7] Desbrow C., Routledge E., Brighty G. et al.: Environ. Sci.

Technol., 1998, 32, 1549. https://doi.org/10.1021/es9707973

[8] Hirai N., Nanba A., Koshio M. et al.: Aquat. Toxicol., 2006, 77,

78. https://doi.org/10.1016/j.aquatox.2005.11.001

[9] Cosnier S., Fombon J., Labbe P., Limousin D.: Sens. Actuators B, 1999, 59, 134. https://doi.org/10.1016/S0925-4005(99)00210-5 [10] Poyard S., Martlet C., Renault J. et al.: Sens. Actuators B, 1999, 58, 380. https://doi.org/10.1016/S0925-4005(99)00100-8 [11] Yin T., Wei W., Zeng J.: Anal. Bioanal. Chem., 2006, 386, 2087. https://doi.org/10.1007/s00216-006-0845-z

[12] Bui M.-P., Ai Li C., Seong G.: BioChip. J., 2012, 6, 149. https://doi.org/10.1007/s13206-012-6207-3

[13] Manjunatha J., Gururaj K.: Eurasian J. Anal. Chem., 2019, 14, em20190001. https://doi.org/10.29333/ejac/20190101

[14] Kamyabi M., Shafiee M.: Braz. J. Chem. Soc., 2012, 23, 593.

[15] Beitollahi H., Karimi-Maleh H., Khabazzadeh H.: Anal. Chem., 2008, 80, 9848. https://doi.org/10.1021/ac801854j 
[16] Sun Y., Fei J., Hou J. et al.: Michrochim. Acta, 2009, 165, 373. https://doi.org/10.1007/s00604-009-0147-1

[17] Ates M., Castillo J., Sarac A., Schuhmann W.: Michrochim. Acta, 2008, 160, 247. https://doi.org/10.1007/s00604-007-0837-5

[18] Ohnuki Y., Ohsaka T., Matsuda H., Oyama N.: J. Electroanal. Chem., 1983, 158, 55. https://doi.org/10.1016/S0022-

0728(83)80338-6

[19] Volkov A., Tourillon G., Lacaze P., Dubois J.: J. Electroanal. Chem., 1980, 115, 279. https://doi.org/10.1016/S0022-

0728(80)80332- 9

[20] Xu F., Gao M., Wang L. et al.: Talanta, 2001, 55, 329.

https://doi.org/10.1016/S0039-9140(01)00432-5

[21] Milczarek G., Ciszewski A.: Electroanalysis, 2004, 16, 1977. https://doi.org/10.1002/elan.200303044

[22] Yu A., Chen H.: Anal. Chim. Acta, 1977, 344, 181.

https://doi.org/10.1016/S0003-2670(97)00016-0

[23] Roy P., Okajima T., Ohsaka T.: Bioelectrochem., 2003, 59, 11. https://doi.org/10.1016/S1567-5394(02)00156-1

[24] Seal B., Otero T., Panitech A.: Mater. Sci. Eng. C, 2001, 34, 147. https://doi.org/10.1016/S0927-796X(01)00035-3

[25] Chen W., Lin X., Huang I., Luo H.: Microchim. Acta, 2005,

151, 101. https://doi.org/10.1007/s00604-005-0376-x

[26] Lakshmi D., Sharma P., Prasad B.: Biosens. Bioelectron., 2007, 22, 3302. https://doi.org/10.1016/j.bios.2006.12.011

[27] Antiochia P., Gorton L.: Biosens. Bioelectron., 2007, 22, 2611. https://doi.org/10.1016/j.bios.2006.10.023

[28] Beitollahi H., Mozhdeh H., Masoud T. et al.: Electroanalysis, 2015, 27, 524. https://doi.org/10.1002/elan.201400635

[29] Manjunatha J., Dearaman M., Basri N., Talib I.: Arab. J. Chem., 2018, 11, 149. https://doi.org/10.1016/j.arabjc.2014.10.009

[30] Manjunatha J.: Sens. Biosensing Res., 2017, 16, 79.

https://doi.org/10.1016/j.sbsr.2017.11.006

[31] Manjunatha J., Deraman M.: Anal. Bioanal. Electrochem., 2017, 9, 198.

[32] Mou A., Ouarzane A., Rhazi M.: J. Electrochem. Sci. Eng., 2017, 7, 111. https://doi.org/10.5599/jese.386

[33] Raril C., Manjunatha J.: Biomed. J. Sci. Tech. Res., 2018, 9, 1. https://doi.org/10.26717/BJSTR.2018.09.001804
[34] Manjunatha J., Deraman M., Basri N.: Asian J. Pharm. Clin. Res., 2015, 8, 48. https://doi.org/10.22159/ajpcr.2017.v10i12.21028

[35] Manjunatha J.: Int. J. Tech. Res., 2016, 9, 136.

[36] Raril C., Manjunatha J.: Mod. Chem. Appl., 2018, 6, 2.

[37] Manjunatha J.: J. Food Drug. Anal., 2018, 26, 292. https://doi.org/10.1016/j.jfda.2017.05.002

[38] Manjunatha J., Dearman M., Basri N. et al.: C. R. Chim., 2014, 17, 465. https://doi.org/10.1016/j.crci.2013.09.016

[39] Nian Bing L., Wang R., Hong Qun L.: J. Solid State Electrochem., 2008, 12, 693. https://doi.org/10.1007/s10008-007-0410-5 [40] Deletioglu D., Hasdemir E., Solak A.: Curr. Anal. Chem., 2010, 6, 203. https://doi.org/10.2174/157341110791517025

Received: July 01, 2019 / Revised: August 29, 2019 /

Accepted: December 13, 2019

\section{ЕЛЕКТРОХІМІЧНЕ ВИЗНАЧЕННЯ ДОПАМІНУ ТА СЕЧОВОЇ КИСЛОТИ 3 ВИКОРИСТАННЯМ ВУГІЛЬНО-ПАСТОВОГО ЕЛЕКТРОДУ, МОДИФІКОВАНОГО ПОЛІПРОЛІНОМ. ЦИКЛІЧНЕ ВОЛТАМЕТРИЧНЕ ДОСЛІДЖЕННЯ}

Анотація. За допомогою циклічної вольтаметрї проведено електрополімеризацію проліну на поверхні вугільнопастового електроду та для індивідуального та одночасного визначення допаміну та сечової кислоти. Морфологію поверхні розробленого електрода вивчено методом емісійної скануючоі електронної мікроскопї. Виявлено, що модифікований електрод виявив високу чутливість струму на допамін порівняно з оголеним електродом. Доведена висока каталітична активність розробленого модифікованого електроду з різним потениіалом окиснення допаміну та сечової кислоти. Встановлено, щзо перебіг електродного процесу контролюється адсорбиією. Показана достатньо непогана стабільність та відтворюваність розробленого методу. За оптимальних умов діапазон кониентрацій становить від $1 \cdot 10^{-4}$ до $2 \cdot 10^{-4} \mathrm{M}$, а межа ви-

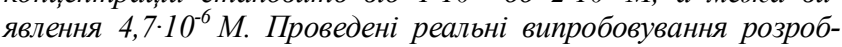
леного електроду із задовільним результатом.

Ключові слова: допамін, сечова кислота, пролін, електрополімеризація, ичикічна вольтаметрія. 